\title{
Application of Tutoring Based on Principles of Learning in Islam Through Strengthening Application Services for Learning Ethics
}

\author{
Affan Yusra* \\ Department Guidance and Counseling \\ Jambi University \\ Jambi, Indonesia \\ affan15yusra@unja.ac.id*
}

\author{
Rasimin \\ Department Guidance and Counseling \\ Jambi University \\ Jambi, Indonesia \\ Rasimin.fkip@unja.ac.id
}

\begin{abstract}
In Islam to get a respectability in learning, ethics must be involved in the process of interaction between learning and teaching takes place. In the context of learning and teaching in an Islamic perspective, learning ethics is a science that explains the feelings, attitudes, and ways of thinking of a claimant of knowledge in learning activities towards moral awareness that communicates the good-bad, good or bad community environment. The purpose of this research is how to apply learning, learning based on the principles of learning in Islam to improve the ethics of learning among students. The sample in this study used 34 students were taken by a purposive sampling technique based on the suggestions in this study. The results after the application of tutoring based on the principles of learning in Islam in accordance with the accepted hypothesis category. Considering learning ethics of learning for students, it is important for counselors to implement learning strategies based on the principles of learning in Islam with steps to improve and make learning ethics in students.
\end{abstract}

Keywords - tutoring based on principles of learning in Islam, content mastery services, learning ethics

\section{INTRODUCTION}

In Islam to get the glory in learning, ethics is important to apply in the learning process. In the context of learning and teaching in an Islamic perspective, learning ethics is a science that explains how feelings, attitudes, and ways of thinking of a claimant in their learning activities towards moral awareness that contain good and bad beliefs, whether or not something is based on the rules that apply in a community environment [1]. Ethics or morality in learning, is a unique mental state that determines human actions based on moral philosophy; Adab is the actual practice of moral philosophy. In addition, Akhlaq described various activities that were marked by Amal Salih or 'pious deeds' in the Al Qur'an [2].

Based on the results of this study indicate that the ethics of learning in the book of 'Limul Muta' allim include learning intentions; choose knowledge, teacher and friend; glorify science and experts; perseverance, continuity, and interest; and study time for scientific prosecutors [3].

According to Al-Ghazali, learning ethics has four concepts, namely 1) oneself, which includes physical and psychological aspects in the form of aspects of faith, morals, aqliyah, social and physical; 2) the teacher must be considered as our own parents; 3) choose lessons that consist of mukasyafah and mu'amalah science; and 4) choosing the best study partner in terms of piety [3]. The four concepts of learning ethics of Al-Ghazali students cannot be separated, but they are a unified whole to form a perfect student personality so that he can succeed in his learning process to gain useful knowledge not only in the world, but also in the end.

The results of the study showed that the respondents' learning ethics were generally quite good (52\% were in the "moderate" category and $28 \%$ were in the "good" category). The learning achievement of Islamic Education Subject namely Pendidikan Agama Islam (PAI) in bahasa respondents was generally quite good $(55 \%$ were in the "enough" category, 32\% were in the "good" category, and $11 \%$ of respondents were in the "very good" category). Tthere is no influence of respondents' learning ethics on learning achievement in PAI subjects. That is, there are other factors that are more influential on PAI's learning achievement. Or maybe it is because PAI's learning achievement in this study is based more on measuring the respondent's cognitive field in PAI science, not based on measuring his religious attitudes and behavior. Even though learning ethics is more a combination of respondents' cognitive, affective, and psychomotor components [4].

Learning ethics that students must possess include; (1) keep away from despicable nature; (2) be serious and work hard in learning; (3) students should not boast about the knowledge they have; (4) should avoid debate; (5) let students learn gradually; (6) students should not learn other knowledge before they master the knowledge they learn; (7) students should not follow subjects that are not yet appropriate; (8) students should learn ways to get useful knowledge; (9) in learning to try to draw closer to God [5].

In the implementation of the learning ethics of students of religious programs in MTsN 2 Kediri, there are 7 ethical points that become a grip when studying for 3 years in this Madrasah, namely 1) Intention when learning, 2) Choosing knowledge, teachers and friends and endurance in learning, 3) Respect for knowledge and scholars, 4) Pray before learning, 5) Perseverance, continuity and noble ideals, 6) Tawakal to Allah, 7) Wara, 2. Supporting factors are 1) Exemplary Principal and Teacher 2) Student 
motivation / determination 3) Parental support for religious class programs in MTsN 2 Kediri 4) Curricula integrated with ethics in learning ethics. In accordance to Islamic education, the inhibiting factors are 1) Not all madrassas give for example, 2) there are lazy students, 3) media are increasingly developing causes students to focus less on their initial intention in learning [6].

However, the opposite is found in daily life among students such as: lack of worship, disrespect and respect for older people / teachers at school, intolerant of differences in both religious and cultural terms. This is not much different from the data obtained from the results of interviews with subject teachers and teachers on May 8, 2019 guidance and counseling in MTsN 2 Jambi City obtained information that there are still students who commit acts that illustrate the lack of student ethics in learning such as: cheating on an exam, students cheating, being indifferent to the assignments given by the teacher, skipping class, lazy to learn, arrogant, falling asleep during class time, engrossed in chatting with friends when the teacher explained the subject matter and received all the knowledge without knowing the origin that knowledge.

This should be a joint concern between parents and subject teacher, guidance and counseling teachers, homeroom teachers and all devices in the school. Guidance and counseling teachers on this issue has an important role as a driving force in paying attention to student learning ethics.

Guidance and counseling teachers have a forum in helping students to improve ethics in learning to be useful for their lives. Guidance and counseling is a container in helping students to improve their learning ethics, so students can apply/practice the knowledge they have gained from the learning process so that it can be useful for daily life. In guidance and counseling, there are various types of guidance. The types of guidance refer to the four main areas, namely: learning, personal, social and career [7].

The field of tutoring, students may get an education that suits their needs, talents, interests, abilities and helps students to determine effective and efficient ways of dealing with learning problems experienced by students [8]. Furthermore, tutoring is guidance in terms of finding the right way of learning, in choosing appropriate study programs, and in overcoming difficulties that arise related to the guidance of learning in an educational institution [9].

In addition to the field of guidance, guidance and counseling has several types of services to overcome individual problems, especially in improving the ethics of learning, one of which is content mastery services. Content mastery services can assist individuals in mastering certain content in order to improve learning ethics. Content mastery service is a counseling service that allows clients to develop themselves with respect to good attitudes and study habits, subject matter that matches the pace and difficulty of learning, as well as various aspects of objectives and other learning activities [10].

This is illustrated in previous studies showing a picture of students before being given content mastery services have an average percentage of learning habits $60.0 \%$ (medium category). After obtaining content mastery services increased to $78.5 \%$ (high category). Based on the analysis of the trials obtained tcount $=13.877$ and ttable $=$
2.042, so the value of tcount> ttable. Based on these calculations there are significant differences between students' learning habits before and after content mastery services are provided [11].

During this time, content mastery services have undergone some development but have not been able to improve learning ethics among students. There are several techniques and approaches that can be used in improving individual learning ethics. One of them is by applying principles-based learning guidance techniques. the principle of learning in Islam.

This study is more devoted to tutoring studied in terms of the science of guidance and counseling. Prayitno suggests that tutoring is an area of guidance aimed at helping students recognize, grow and develop themselves, good learning habits to master knowledge and skills and prepare them to continue their education at a higher level [10].

Tutoring based on the principles of learning in Islam can be interpreted as a process of providing assistance carried out by guidance and counseling teachers to students who experience obstacles in learning, helping students find appropriate learning methods, choosing courses according to their desires through the values of Islamic teachings that are used as a basis for thinking or grounding and a source of motivation so that the learning process can run well between teachers and students [11]. Starting from the background above, the researcher interested in conducting a study entitled Application of Guidance based on the principles of learning in Islam through content management services to improve learning ethics in students of MTsN 2 (MTsN Model) Jambi City. The objective of this study is the implementation of Guidance-Based Learning Principles in Islam through Content Mastery Services to Improve Learning Ethics in MTsN 2 Students (MTsN Model) Jambi City.

\section{METHODS}

\section{Study Design and Study Population}

The method used in this study is classroom action research by practical research conducted to improve learning in the classroom. This research use desciptive qualitative approach. Actions on the subject class. This research was conducted in two cycles, each of which was carried out in two cycles using four stages: action plan, implementation, observation, and reflection.

The four stages of classroom action research include the following:

1) Develop a plan

At this stage, the activities are making lesson plans, preparing facilities from the supporting facilities needed in class, preparing instruments to record and analyze data regarding the process and results of actions.

2) Carry out the action (acting).

At this stage the researcher carries out the actions that have been formulated in the CSP, in actual situations, which include initial, core and closing activities.

3) Carry out observations

At this stage the thing to do is to observe the behavior of the students who are following the learning activities. 
Monitor discussions or collaborative activities between groups observing the understanding of each student in the mastery of learning material, which has been designed according to CAR.

4) Reflecting

At this stage, what needs to be done is recording the results of observations, evaluate the results of observations, and analyze learning outcomes, record weaknesses to be used as material for the design of the next cycle until the goals of CAR are achieved.

The subject of this the students of MTsN 2 Jambi City who are in class VIII with a population of 120 students. In determining the sample the researcher used a porous positive sampling technique.

Data were collected using test questions, observation sheets. Data analysis can be done in the following ways: (1) Classifying data by grouping, selecting, focusing, and simplifying data according to the type from the start of data collection to report preparation; (2) Presentation of the selected data will be presented in the form of simple information. The information referred to a description of the process of providing guidance and the results obtained from a combination of observation data; (3) Based on exposure, conclusions will be obtained in the form of short sentences but have a broad meaning. From the conclusions are used to test the truth and match the meaning of the data obtained in the field.

Student questionnaire results regarding the results obtained from cognitive test scores at the end of each cycle. To find out the increase in student learning ethics seen from the results of observations and student ethics learning questionnaire in each cycle consisting of individual completeness and classics with a level of achievement of $75 \%$, students stated their learning ethics increased.

\section{Data collection and measurement}

The sample of this study was a class with a total of 34 students. Data was collected and then tabulated, which explained the learning ethics. Students must have; (1) keep away from blameworthy; (2) serious and work hard in learning; (3) students may not boast about their knowledge; (4) avoid debate; (5) learn gradually; (6) students may not study other sciences until they have mastered the knowledge learned; (7) students may not attend subject matter that is inappropriate to be followed; (8) students must learn how to get useful knowledge; (9) in learning to try to get closer to Good.

The questionnaire also included an assessment of students' knowledge about learning ethics in Islam. The participants responded to the questionnaire without outside intervention initially where the questioner was given each correct answer. A brief assessment was then carried out on the same individual to evaluate students' knowledge about the same thing after being given guidance based on the principles of learning in Islam. In fact, after attending tutoring based on the principles of learning in Islam, it can be seen that a score is given for each good response. tutoring based on the principles of learning in Islam conducted by the counselor is given to all participants in one class and aims to increase students' knowledge and awareness of what influences the ethics of learning in Islam.

\section{Statistical analysis}

Statistical analysis was performed using the Statistical Package for Social Sciences (SPSS) (version 21.0), IBM, New York, USA. Descriptive analysis is performed for demographic data. Continuous variables are expressed as mean \pm standard deviation and categorical variables as numbers and percentages. Paired sample t test was used to compare scores between before and after guidance based on the principles of learning in Islam. Results were considered statistically significant for $\mathrm{p}<0.05$. For multivariate analysis, the principles of learning in Islam are carried out as dependent variables, independent learning ethics variables.

\section{RESULT AND DISCUSSION}

\section{Implementation of Guidance-Based Learning Principles in} Islam Through Content Mastery Services

Implementation of tutoring based on the principles of learning in Islamic learning is carried out with two cycles, each of which has two actions. Stages of guidance activities consist of: discussing topics, developing and presenting reports, analyzing, and providing tutoring based on the principles of learning in Islam.

The implementation of the study guidance study starts from the planning stage of the joint planning plan with regard to suggestions and input. At the planning stage, follow the guidance material on learning about yourself and the nature of learning, the importance of having a critical attitude in learning, the importance of being honest in exams, evaluation sheets, instruments, and guidelines for implementing tutoring activities, and guidance material. The format prepared includes the observation format and the order in which the research was conducted. This format is structured to document all learning activities in the implementation of tutoring so that accurate reflection can be carried out. In addition, Lesson Study team members also plan and develop complete learning tools and instruments for the needs of the implementation phase (plan), namely the preparation of a tutoring plan, handout material, student activity sheets, observation sheets for the activities of researchers, teachers and students in learning problems .

The next stage is the implementation phase (do) by researchers and teachers as a model that implements the previous guidance plan. The initial stage in this stage shows the model of researchers and teachers who provide perceptions, motivations, and explain the tutoring model. The implementation of tutoring is divided into five activities, namely the initial activities of the core activities consisting of the stages of student orientation towards the problem; organizing students to study; guide individual and group investigations; develop and present work; and analyze and evaluate the learning process; and the last activity. This is in accordance with the learning plan with a model of tutoring based on the principles of learning in Islam, with the help of three members of the study team the lesson will observe the activities carried out by researchers, teachers and students in the learning process.

At the reflection stage (see), reflection from the results of the learning guide is carried out in accordance with the implementation of the service content mastery activity and analyzes the overall learning that has been done. At this stage, it is carried out jointly by all existing 
components, both groups of teachers and researchers and subject observers, because the results of the discussion and analysis can be used as input to improve or revise the next lesson.

In the reflection phase (see), the reflection of the learning outcomes is carried out in accordance with the implementation of the tutoring activity and analyzes the overall guidelines that have been carried out. At this stage, all components of both the subject teacher and observer groups are present together, because the results of the discussion and analysis can be used as input to refine or revise the next lesson.

For teachers and researchers, not previously discussed with group members. The teacher's activity time has not been effective, especially for discussion time and time for presentation. During the discussion, the teacher and researcher did not confirm the time allotted for discussion, so students stopped during the discussion. The teacher does not provide time management so there is free time that students use to joke alone. Students are still difficult to express reasons for answers given, still shy to ask questions, answer questions or answer.

The process of applying tutoring based on the principles of learning in Islam carried out in this study is direct experience. Through tutoring based on the principles of learning in Islam it can be seen that many students are smart but they have many challenges in learning as happens in the direct material they get [11].

Problem of tutoring based on the principles of learning in Islam to improve student learning ethics

Guidance is a guide to the correct way of learning, in choosing study programs, and able to overcome difficulties. [12] In this process, $\mathrm{s}$ gives the meaning of Islamic Guidance and Counseling as "A process in tutoring that is carried out based on Islamic teachings, to help individuals who have problems to reach the world and the happiness of the hereafter [13]. Ethics of learning is a human behavior that accumulates knowledge that comes from human thought patterns, either manifested from attitudes, behaviors, or in accordance with norms [14].

Quoted from the results of similar research his research is the concept of al-Ghazali science has implications for ethics in studying, namely: (1) Student ethics towards him, where a student must be able to place and heat themselves to study; (2) Student ethics towards the teacher, is a student's respect for the teacher as the person chosen to guide in studying; (3) The students' ethics towards their knowledge, which a student must be able to use his knowledge and practice it by not undermining the knowledge he has and the knowledge he does not have [15].

Implementation of the research can be seen in the table below: The first cycle is conducted in two meetings Based on pre-school studies, pre-tests conducted by students at the beginning of learning (before action) obtain data in table 2. While the results of posting tests conducted by students after the actions in table 3 .

From the above data it can be seen that the average post-test score of students is 80,70 . In addition, the percentage of students completeness in the post-test cycle is $70.25 \%$. This means that the percentage of completeness in my cycle. still not reach $75 \%$. To measure learning ethics is not only done by distributing questionnaires, but learning guidance is carried out with three observers.

\section{Comparison of cycle I and cycle II}

Based on observations of the achievement of the actions of researchers and teachers in applying tutoring based on the principles of learning in Islam and student achievement in learning activities during the first cycle and the second cycle, as well as data that has been collected and analyzed, the percentage of student achievement shows an increase. Implementation of action research activities in the application with a guideline model based on principles of learning in Islam can be seen below Table 4.

Based on preliminary observations made by researchers, it is known that the daily test scores of many students are below the minimum completeness criteria set at $\mathrm{MTsN} \geq 75$. The teacher has used a tutoring model based on the principles of learning in Islam in the following forms: discussion, various lectures, and practices. question. However, the results of their tutoring on students are still not satisfactory and meet the minimum completeness criteria (KKM) that have been set.

Quoted from the results of similar research his research is the concept of al-Ghazali science has implications for ethics in studying, namely: (1) Student ethics towards him, where a student must be able to place and heat themselves to study; (2) Student ethics towards the teacher, is a student's respect for the teacher as the person chosen to guide in studying; (3) Ethics of students against their knowledge, which a student must be able to take advantage of his knowledge and practice it by not undermining the knowledge he has and the knowledge he does not have [15].

Inversely proportional to this research activity as in group discussion activities, there are still many students who joke with other group members. Iskusi activity is only dominated by certain students so that other students still lack the courage to express their opinions. At the end of the first learning cycle when the teacher gives a test (post-test) many students who are not ready to do the test can be seen from many students who were caught cheating answers from their peers. To understand the lesson, students do it by memorization. How student guidance will affect the ethics of student learning will be obtained. Student learning ethics is not only influenced by the way students learn, but is also influenced by how to give the school counselor ways to provide tutoring that is done by the teacher, teachers who can enter the tutoring methods, resources and learning media used.

\section{CONCLUSION}

The results of observations of implementation in the first cycle are in the good category while observations of the implementation of the second cycle in this category are very good. The implementation of tutoring based on the principles of learning in Islam can remind students of ethical learning, this can be seen from the increasing observation cycle of student learning achievement I and cycle II. Guidance based on principles in Islam through content mastery services has been carried out well including the completeness of media guidance tools and preparing guidance plans before service provision, in each provision of study guidance materials based on the application of tutoring 
based on learning The principles in Islam can be concluded that the use of tutoring based on the principles of learning in Islam can improve student learning ethics.

Schedule of the implementation of tutoring based on the principles of learning in Islam through content mastery services and research procedure is attached on the table below.

Table 1. Schedule of The Implementation of Tutoring Based on The Principles of Learning in Islam Through Content Mastery Services

\begin{tabular}{|c|c|c|c|c|c|}
\hline \multirow[b]{2}{*}{ No } & \multicolumn{5}{|c|}{ Implementation Schedule } \\
\hline & Cycles & $\begin{array}{l}\text { Stage } \\
\text { Plan }\end{array}$ & Do & See & $\begin{array}{l}\text { Guidance } \\
\text { materials }\end{array}$ \\
\hline 1 & I & $\begin{array}{lr}\text { Plan } & \text { I, } \\
\text { Juli } & 29, \\
2019 & \end{array}$ & $\begin{array}{l}\text { Do I, } \\
\text { Juli } 31 \text {, } \\
2019\end{array}$ & $\begin{array}{c}\text { See I, } \\
\text { Juli } 31 \text {, } \\
2019\end{array}$ & $\begin{array}{c}\text { Know } \\
\text { yourself }\end{array}$ \\
\hline 2 & I & $\begin{array}{l}\text { Plan II, } \\
\text { Agustus } \\
5,2019\end{array}$ & $\begin{array}{c}\text { Do II, } \\
\text { Agustu } \\
\text { s 7, } \\
2019\end{array}$ & $\begin{array}{c}\text { See II, } \\
\text { Agustu } \\
\text { s 7, } \\
2019\end{array}$ & $\begin{array}{c}\text { The Nature of } \\
\text { Learning }\end{array}$ \\
\hline 3 & II & $\begin{array}{l}\text { Plan III, } \\
\text { Agustus } \\
12,2019\end{array}$ & $\begin{array}{c}\text { Do III, } \\
\text { Agustu } \\
\text { s } 14, \\
2019\end{array}$ & $\begin{array}{c}\text { See III, } \\
\text { Agustu } \\
\text { s 14, } \\
2019\end{array}$ & $\begin{array}{c}\text { The } \\
\text { importance of } \\
\text { having a } \\
\text { critical } \\
\text { attitude in } \\
\text { learning }\end{array}$ \\
\hline 4 & II & $\begin{array}{l}\text { Plan IV, } \\
\text { Agustus } \\
16,2019\end{array}$ & $\begin{array}{c}\text { Do IV, } \\
\text { Agustu } \\
\text { s 20, } \\
2019\end{array}$ & $\begin{array}{c}\text { See IV, } \\
\text { Agustu } \\
\text { s 20, } \\
2019\end{array}$ & $\begin{array}{l}\text { The } \\
\text { importance of } \\
\text { being honest } \\
\text { in } \\
\text { examinations }\end{array}$ \\
\hline
\end{tabular}

Table. 2 Students' score before action

\begin{tabular}{|l|c|}
\hline \multicolumn{1}{|c|}{ Pre Test } & Score \\
\hline Average Score & 68,80 \\
\hline Percentage of mastery & $50,6 \%$ \\
\hline
\end{tabular}

Table. 3 Post-test after action

\begin{tabular}{|l|c|}
\hline Average Score & Score \\
\hline Percentage of mastery & $70,25 \%$ \\
\hline Average Score & 80,70 \\
\hline
\end{tabular}

\section{ACKNOWLEDGMENTS}

1. Thank you very much to the University of Jambi for funding the author's research is fully funded by DIPA
PNBP LPPM UNJA in research institutions and community service institutions at Jambi University with contract No; B717 / UN 21.18 / PT.01.03 / 20019.

2. Thank the authors say to all leaders and ranks of MTsN 2 Jambi City who have been willing to provide a place for the implementation of this research.

3. Thank the authors say to the instrument validator who has been willing to validate this research instrument.

\section{REFERENCES}

[1] Magfirah. 2014. Etika Belajar. Universitas Islam Negeri Syarif Hidayatullah: Jakarta.

[2] Ebrahimin \& kamaruzaman. 2017. Islamic Identity, Ethical Principles and Human Values. Jurnal Penelitian.

[3] Khuluk. 2010. Konsep Etika Belajar Menurut Al-Gazali. Universitas Islam Negeri Syarif Hidayatullah: Jakarta.

[4] Ramdani. 2014. Pengaruh Etika belajar Terhadap Prestasi Belajar siswa PAI. Universitas Pendidikan Indonesia: Bandung.

[5] Iqbal. 2013. Konsep Pemikiran Al- Gazali Tentang Pendidikan, Jaya Star Nine. Jawa Timur.

[6] Nidhomuddin, M. D. Z. F., \& Muslimin, M. (2018). Implementasi Etika Belajar Dalam Perspektif Pendidikan Islam pada Siswa Program Kelas Religi: Studi Kasus di MTsN 2 Kota Kediri. Jurnal Intelektual: Jurnal Pendidikan Dan Studi Keislaman, 8(3), 291-302. Retrieved from https://ejournal.iai-tribakti.ac.id/index.php/ intelektual/article/view/74.

[7] Hamalik, Oemar. 2014. Proses Belajar Mengajar. PT Bumi Aksara: Jakarta.

[8] Sukardi, 2008. Pengantar Pelaksana Program BK di Sekolah. Rineka Cipta: Jakarta.

[9] Prayitno.2018. Konseling Professional yang Berhasil. Jakarta: Bumi Aksara.

[10] Istiqomah. 2014. Pengaruh Layanan Konten Terhadap Kebiasaan belajar Pada Siswa Kelas Viii B SMP Tamtama Kemranjen Banyumas Tahun Ajaran 2013/2014. Universitas Negeri Semarang. Semarang.

[11] Yusra, Affan, Dwi Yuwono Puji Sugiharto, and Anwar Sutoyo. "Model Bimbingan Belajar Berbasis Prinsip-prinsip Belajar dalam Islam untuk Meningkatkan Kemanfaatan Ilmu." Jurnal Bimbingan Konseling 6, no. 2 (2017): 106-112.

[12] Fiah \& adi" Penerapan Bimbingan Belajar Dalam Meningkatkan Hasil Belajar Peserta Didik di Smp Negeri 12 Kota Bandar Lampung Tahun Pelajaran 2015/2016' Konseli: Jurnal Bimbingan dan Konseling 03 (2) (2016) 229-244.

[13] Mahmudi.2014. Pembentukan Karakter Melalui Layanan Bimbingan Dan Konseling Islami.Jurna bimbingan dan konseling consellia. No 1 Vol 3.

[14] Rosiama. 2017. Etika Menuntut Ilmu Dalam Kitab Washoya Karya Muhammad Syakir.

[15] Sobari, dkk. 2017 Konsep Ilmu menurut Imam Al-Ghazali dan Implikasinya terhadap Etika dalam Menuntut Ilmu. Universitas Islam Bandung: Bandung. 